\title{
A tőkeminimum hatása a magyar hitelkamatokra
}

\section{The effect of Minimum Capital on the Hungarian Loan Interest Rates}

\begin{abstract}
A kutatás célja a hitelkamatok szintjének vizsgálata a minimumtőkeszint függvényében. A vizsgálat úgynevezett „mapping” módszer alkalmazásával a bankszektorra felépített aggregált adatok segítségével állapitja meg a hitelkamat növekedését 1\%-os tőkemegfelelésimutató-emelkedés mellett. A modell alapfeltevése, hogy a banki jövedelmezöség állandó marad, a bank üzleti stratégiája és portfoliókockázata nem változik. Az üzemméret szerinti különbségek azonosítása érdekében az elemzésben a Magyarországon müködő kereskedelmi bankok méret szerinti csoportosításban szerepelnek. Az eredmények alapján a tőkemegfelelési mutató 1\%-os emelése a nagybankok esetében mutatja a legmagasabb, 18 bázispontos növekedést a hitelek kamatszintjében. Ez alapján a hitelkamat emelkedése nem jelentős mértékü, és összhangban van a korábbi empirikus kutatások eredményével. Az elemzés hozzájárul a tőkeszabályozás és a banki jövedelmezöség közötti kapcsolat felméréséhez, és segiti a hitelkamat-növekedés elörejelzését a változó töke-és kamatszint mellett.
\end{abstract}

Kulcsszavak: Bázel III., nemzetközi pénzügyi szabályozás, tőkemegfelelés, tőkeemelés, kamatszint, hitelezés

The aim of the research is to examine the level of loan interest rates, in line with minimum capital level increase in the Hungarian banking sector. The model uses the mapping method, with aggregated data for the banking sector, which determines the increase in the loan interest rate in case of a $1 \%$ per cent capital adequacy ratio increase. The basic assumption of the model is that the bank's profitability will remain constant and the bank's business strategy and portfolio risk will remain the same. In order to identify the differences in the size of the financial institutions, the Hungarian commercial banks are grouped in three categories on the basis of their total assets (small, medium and large banking groups). Based on the results, a 1 per cent increase in the capital adequacy ratio for large banks shows the highest 18bp increase in the interest rates of the loans. The loan interest rate increase is not significant and it is

Füzesi Krisztina a Budapesti Corvinus Egyetem Nemzetközi Kapcsolatok Multidiszciplináris Doktori Iskola Világgazdaság Tanszék doktori hallgatója. E-mail: krisz0903@gmail.com 
in line with the results of the previous empirical research. The analysis contributes to the assessment of the relationship between capital regulation and bank profitability and helps to predict the growth of credit interest rates in an increasing minimum capital level or base rate environment.

Keywords: Basel III, international financial regulation, capital adequacy, minimum capital level, interest rate

\section{Bevezetés}

A 2007-es gazdasági válság során felfedezett pénzügyi gyengeségekre adott szabályozói válasz a Bázel III., amelynek rendelkezéseit az Európai Parlament és Tanács 2013/36/ EU ${ }^{1}$ irányelve (CRD IV) és 575/2013/EU² rendelete (CRR) fogalmazza meg az Európai Unióban. A szabályozás középpontjában továbbra is a minimum tőkekövetelményre vonatkozó szabályok állnak, emellett a szabályozás magasabb likviditási és egyéb kockázatkezelési sztenderdeket is előír a bankok számára. Jelentős újítás a rendszerszintű szemlélet, amely az úgynevezett makroprudenciális előírásokkal a válságjelenség átterjedésének valószínűségét, vagyis a pénzügyi fertőzéses hatást kívánja csökkenteni. A szabályozás célja a pénzügyi rendszer stabilitásának növelése, hatása azonban az aktuális nemzetgazdasági és monetáris politikai körülmények között vizsgálandó. A szabályozás egyik lehetséges és széles körben vizsgált következménye a hitelkamatok szintjének növekedése, amely elsősorban a szabályozásból eredő minimumtőkeszint emelkedéséből adódik. A kutatás célja ennek a hatásnak a felmérése Magyarországon, továbbá annak vizsgálata, hogy a tőkemegfelelési mutató 1\%-os emelkedése milyen mértékben emeli a hitelek kamatszintjét. A kutatási kérdések megválaszolását Matejašák tanulmányában alkalmazott, úgynevezett „mapping” modell segíti. A vizsgálat feltételezi, hogy a bankok a sajáttőke-arányos megtérülési mutató (Return-on-Equity - RoE) maximalizálására törekszenek, amelynek elsődleges forrása a kamatbevétel. ${ }^{3}$

A téma aktualitását a minimumtőkeszint graduális emelése adja, amely a bázeli alkalmazkodási folyamat része, továbbá a téma feldolgozása segíti a felügyeleti és monetáris politikai intézkedések között fellépő esetleges kölcsönhatások azonosítását, amely egy kamatemelési ciklus során kulcsfontosságú lehet. A vizsgálat eredménye kiegészíti a cseh bankszektorra készített kutatást, ${ }^{4}$ és segíti a kelet-közép-európai régió pénzügyi folyamatainak megértését. A szakcikk első része - a téma elméleti hátterét érintve - a tőkeemelés gyakorlati hatásait ismerteti, majd bemutatja a modellt és annak megvalósítását a magyar bankpiac vonatkozásában.

Az Európai Parlament és a Tanács hitelintézetek tevékenységéhez való hozzáférésről és a hitelintézetek és befektetési vállalkozások prudenciális felügyeletéről szóló 2013/36/EU irányelve (CRDIV).

2 Az Európai Parlament és a Tanács hitelintézetekre és befektetési vállalkozásokra vonatkozó prudenciális követelményekről szóló 575/2013/EU rendelete (CRR).

3 Milan Matejašák: Basel III: Will Borrowing Money from Czech Banks Become More Expensive?. European Financial and Accounting Journal, 9. (2014), 2. 9-13.

Matejašák (2014) i. m. 4. 


\section{Elméleti háttér}

Az 1990-es évek végéig az európai pénzügyi szabályozás és felügyelet egyértelmúen nemzeti hatáskörbe tartozott. A szabályozás mikroprudenciális elveken alapult, az egyes bankok tevékenységét, múködését és folyamatait egymástól függetlenül nemzetállami törvények alapján ellenőrizték, és a működési hibákat szankcionálták. Azonban a pénzügyi piac kiterjedése, a növekvő európai integritás és a kialakuló pénzügyi egyensúlytalanságok következtében megszületett az igény egy egységes nemzetközi szabályozás létrehozására, amelynek eredménye a bázeli keretrendszer kidolgozása.

A szabályozás első fontos állomása az első Bázeli Egyezmény (International Convergence of Capital Measurement and Capital Standards - Bázel I.) az egységes nemzetközi tőkekövetelményekről és azok méréséről, amelyet 1988-ban adtak ki. A szabályozás középpontjában a hitelkockázat kezelése állt, amelynek érdekében létrehozták a tőkemegfelelési mutatót. A mutató a kockázattal súlyozott eszközérték (Risk Weighted Asset - RWA) és a tőkekövetelmény hányadosa, amelynek értékét $8 \%$-os szinten rögzítették. Az RWA elméleti meghatározása az irányelv alapján az egyes eszközök kitettségének értéke és a hozzájuk tartozó kockázati felár szorzata. A Bázel I. esetében a standard kockázati felár tartalmazza az esetleges hitelkockázat, felhígulási, múködési, devizaárfolyam, árukockázat és elszámolási kockázat szintjét. A kockázattal súlyozott eszközértékkel szemben álló tőkekövetelmény vagy más néven szavatoló tőke olyan tartalék, amely biztosítja a hitelintézet mindenkori fizetőképességét (szolvenciáját), az általa végzett tevékenység kockázatának figyelembevételével. A Bázel I. előírásait fejlesztették tovább 2006-ban, és hatályba lépett a Bázel II. ajánlás a bankok tőkekövetelményére vonatkozóan. A szabályzat kiegészült az RWA számításához használatos statisztikai modellekkel és nyilvánosságra hozatali követelményekkel is, az egyenlő piaci verseny erősítése érdekében. Jelentős változás, hogy az RWA megállapításánál lehetővé tette a bankok számára a belső veszteség előrejelző modellek és kockázatkezelési folyamatok alapján történő számítást. Vagyis amennyiben a bank alacsonynak ítéli meg a várható veszteség valószínúségét, akkor csökkentheti a kockázatnak kitett eszközértéket, és összességében a tőkeszint növekedése nélkül nőhet a tôkemegfelelési mutató. ${ }^{5}$

A Bázel II. szabályozás kidolgozásával és hatálybalépésével párhuzamosan azonban átalakult a gazdasági környezet és rávilágított a szabályozás kiterjesztésének szükségszerűségére. A fejlett országokban, az általánosságban magas, 5-6\%-os GDP-növekedés mellett az alacsony infláció támogatta az adósságállomány növekedését. Az Európai Unió bővült, a határokon át szabadon áramló tőke és munka egy nemzetközileg összefüggő, szövevényes pénzügyi rendszert teremtett. Magyarországon az 1990-es években megjelentek a külföldi befektetők, és kialakult a kétszintű bankrendszer. A 2000-es évek elejétől 2008-ig a magánszektor banki hitelállománya megduplázódott, és a bankrendszer mérlegfőösszegének GDP-hez viszonyított aránya 60\%-ról 120\%-ra növekedett. A mérlegszerkezet változásai azonban veszélyeztették a bankrendszer stabilitását. A magánszektoron belül a háztartási hitelek állománya GDP-arányosan 8\%-ról 30\%-ra növekedett, miközben a vállalati szektor hitelállománya csupán 21\%-ról 32\%-ra

Amund Holmsen: The theoretical background for macroprudential policy. Norges Bank's Finance Workshop, Oslo, 9 October, 2014.

Európai Tükör 2020/4. 
emelkedett, és a portfólión belül jelentősen nőtt a projekt finanszírozású hitelek aránya. A gazdaság sérülékenységét növelte, hogy a kis- és középvállalkozások és a háztartások körében is elterjedt a devizahitelezés, lazuló hitelezési feltételek mellett. A hiteleket egyre kockázatosabb ügyfélszegmens részére, hosszabb futamidő mellett, magas fedezettségi szinttel és jövedelemarányos törlesztőrészlettel értékesítették. Bekövetkezett a háztartások túlzott eladósodottsága. A hitel-betét arány 156\%-ra emelkedett, miközben nőtt a drága és kockázatosan megújítható külföldi források aránya. A bankok fokozott árfolyamkockázatot és lejárati kockázatot futottak a mérlegben eszközoldalon megjelenő, növekvő mértékű hosszú lejáratú, devizaalapú jelzáloghitelek miatt. Eközben forrás oldalon a rövid távra lekötött forintbetétek álltak, illetve a válság miatt egyre kockázatosabbá váló deviza swapok, amelyek a nyitott pozíciók fedezésére szolgáltak. ${ }^{6}$ Az Amerikai Egyesült Államokból induló 2008-as válság negatív hatásait a hasonló egyensúlytalanságok erősítették. A pénzügyi nehézségek egész Európára kiterjedtek a külföldi tulajdonú bankokon és pénzügyi csatornákon keresztül. ${ }^{7}$ A bankok rendszerszinten jelentős veszteséget könyveltek el, a bankmentésre szánt összegek sok esetben növelték az államadósságot és késleltették a válságból való kilábalást.

A Bázel III. szabályozás 2013-as bevezetése a mérlegszerkezet hasonló eltolódásait hivatott megelőzni és a rendszerkockázatot csökkenteni. A likviditás ellenőrzése érdekében új mutatóként jelenik meg a likviditási fedezeti ráta és a nettó stabil forrásarány, míg a túlzott kockázatviselés korlátozását a tőkeáttételi mutató segíti. A rendszerszintủ fertőzéses hatások csökkentése érdekében a bankközi ügyleteket érintő tőkekövetelmények három-négyszeresére emelkednek, és a partnerkockázati tőkekövetelmények is szigorodnak. ${ }^{8}$ A szabályozás minimum-tőkekövetelménnyel kapcsolatos célja a tőke minőségének javítása és a tőkeáttételi mutató maximalizálása. Az új szabály alapján beszámítható tőkeelemek fő rendezőelve a tőke veszteségfedezeti képessége. Alapvető tőkeként kezelhető az a mérlegtétel, amely a veszteség felmerülésének pillanatában képes fedezni a veszteségeket, míg a másodlagos tőkeelemek fedezetként való érvényesítése csak felszámolás után lehetséges. A szabály meghatározza Az elsődleges alapvető tőke (CET1) fogalmát, amely a legerősebb minőségű, legjobb veszteségviseléssel rendelkező tőke, szigorú minőségi követelményekkel. CET1 tőkeelemként elfogadható a jegyzett tőke (törzsrészvények, részjegyek stb.), a jegyzett tőkéhez kapcsolódó ázsió, eredménytartalék (évközi eredmény csak felügyeleti engedéllyel), egyéb átfogó jövedelem és egyéb tartalékok. A következő minőségi szinten a Tier1-es tőkeelemek állnak, adósság- és tőkejellemzőkkel együttesen rendelkező hibrid tőkeelemek és kapcsolódó ázsió. A CET1 és Tier1 tőkeelemek együttesen alkotják a kiegészítő alapvető tőke csoportját (AT1), amelyet a járulékos (Tier2) tőkeelemek egészítenek ki. Tier2-es minősítésú tőkeinstrumentumok az alárendelt kölcsöntőke és az ezekhez kapcsolódó ázsió.

$6 \quad$ Fábián Gergely - Vonnák Balázs (szerk.): Átalakulóban a magyar bankrendszer. Vitaindító a magyar bankrendszerre vonatkozó konszenzusos jövőkép kialakításához. MNB-tanulmányok, (2014), különszám. 9-11.

$7 \quad$ Kutasi Gábor: Multinational Banks: Protective Factors of Financial Stability in Central and Eastern Europe? In Szent-Iványi Balázs (szerk.): Foreign Direct Investment in Central and Eastern Europe: Postcrisis Perspectives. New York, Basingstoke, Palgrave, 2017. 171-192.

8 Szombati Anikó: Bázel III. rendszerszintủ hatásai itthon és Európában. MNB Szemle, 5. (2010), 4. 33-42. 
A tőkemegfelelési mutató értéke továbbra is 8\%-ban van meghatározva, amelynek összegét az úgynevezett Pillér I-es minimumtőkeszint mutatja. Az összetétele azonban a korábbi szabályozásnál jobb minőségü ${ }^{9}$ tőkeelemeket feltételez a következő bontás szerint: a CET1 tőkeelemek aránya (törzsrészvények és visszatartott nyereség) minimum 4,5\%, AT1 (CET1+Tier1) aránya maximum 1,5\%, és Tier 2 (járulékos tőkeelemek) tőke aránya maximum $2 \%$.

Az alapvető tőkeelem ezen kívül szükség esetén kiegészíthető a tőkepufferekkel is. A szabályozás GDP-arányos, kockázatfüggő, úgynevezett anticiklikus tőkepuffert is tartalmaz. A tőkepufferek alkalmazását a nemzeti felügyeleti hatóság irányítása alapján határozzák meg és ellenőrzik, figyelembe véve a pénzügyi intézmény tőkeellátottságát, üzleti és hitelezési kockázatát és az aktuális makrogazdasági környezetet.

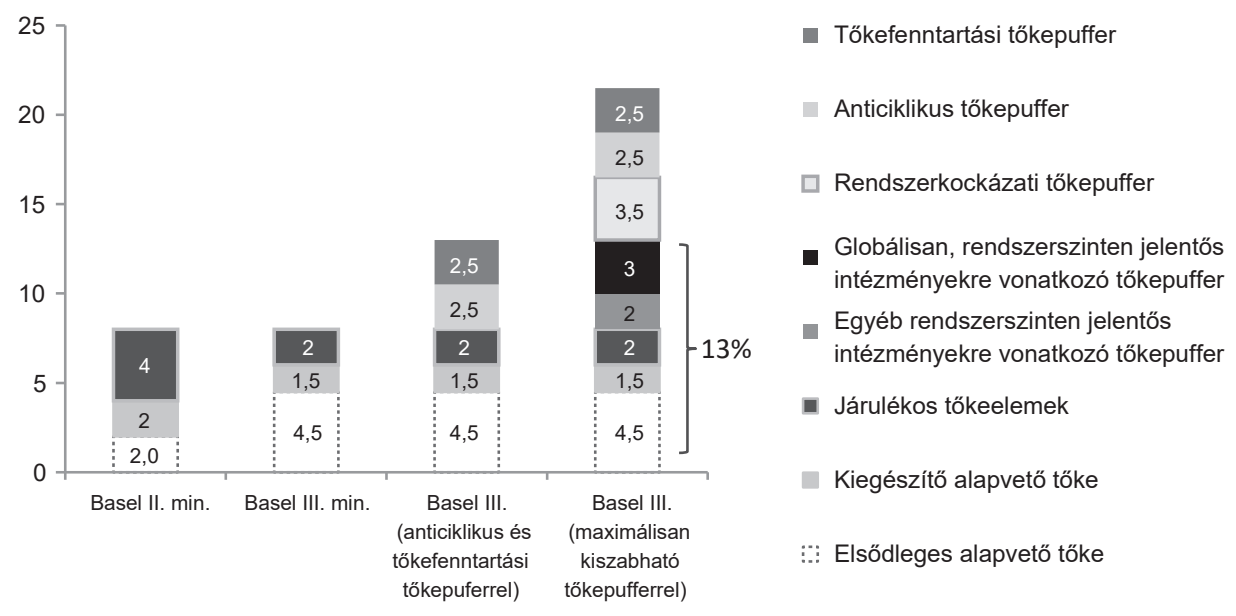

1. ábra

Bázel III. tökekövetelmények alakulása

Forrás: a szerző szerkesztése

Az ábra a tőkekövetelmények szigorítását mutatja a Bázel II. és Bázel III. szabályozás viszonyában, vagyis a CET 1-es, legjobb minőségű tőkekövetelmény 2\%-ról 4,5\%-ra való emelését és az addicionális tőkepufferek arányát. A változtatások eredményeképpen a tőkemegfelelési mutató $20 \%$ fölé is emelkedhet a magas hitelezési kockázat hatására. A Magyarországon müködő bankokra vonatkozó tőkekövetelményt végső soron a Magyar Nemzeti Bank határozza meg évente egy felügyeleti vizsgálat keretein belül. Céljuk a bázeli alapelvet követve az anticiklikus tőkeképzés, amely felívelő gazdasági ciklusban többlettőke képzését támogatja, míg lassuló gazdasági környezetben lazít az elvárásokon. Az Állami Pénz- és Tőkepiaci Felügyelet (Felügyelet) az aktuális gazdasági helyzet, a banki üzleti modell, hitelezési és kockázatkezelési folyamatok és meglévő eszközök kockázatosságának felmérése után adja meg az úgynevezett felügyeleti

Jobb minőségű tőkeelem: legjobb veszteségviseléssel rendelkező tőkeelem: jegyzett tőke (törzsrészvény, részjegyek), jegyzett tőkéhez tartozó ázsió, eredménytartalék és egyéb tartalékok. 
tőketöbblet (Supervisory Review and Evaluation Process - SREP) rátát. A ráta a Pillér I-es tőkekövetelmény viszonyában határozza meg azt a többlet-tőkekövetelményt, amelyet a Pillér I-es tőkeszinten felül képezni szükséges. Így a minimum elvárt tőke a Pillér II-es minimumtőkeszint (Pillér I + többlet-tőkekövetelmény) és az előírt tőkepufferek összegeként írható fel. A többlettőke szintje egyedi vizsgálat eredménye, a Pillér I-es szint esetében használt arányok mentén kell biztosítani, de ettől a Felügyelet szigorúbb irányban eltérhet.

A tőkeminimum legnagyobb részét a hitelkockázatra képzett tőke adja, ezért a gyakorlati tőkeszámítás kulcskérdése az RWA számítása, amely a tőkemegfelelési mutató nevezőjét adja. Az RWA számítására kettő eljárás alkalmazható, az úgynevezett sztenderd és fejlett, vagy más néven belső minősítésen alapuló módszer, amelyek eszközosztályonként meghatározzák a hitelkockázati felárat. A sztenderd módszer a Felügyelet által meghatározott kockázati súlyokkal számol, amíg a belső minősítésű modellekben a bank saját veszteségadatain alapuló tőkekövetelmény-meghatározás történik. Alapvetően a fejlett módszer szerint, ha egy bank ügyfélminősítése jobb, alacsony előre látható veszteségre számíthat, és kevesebb tőkekövetelményre. Amíg a tőkepuffereket inkább a nagyobb, rendszerszinten jelentős bankok esetében számolják fel. Az új tőkeszabályok bevezetésével a Magyarországon alkalmazott módszertan is fejlődött, és az előre látható veszteségre vonatkozó kalkuláció időről időre nagyobb tőkekövetelményt jelent. A magyar bankfelügyelet utolsó auditált adatai szerint a magyar bankrendszer tőkemegfelelése jóval a szabályozói minimum felett áll. Aggregált adatok alapján 2018. decemberben 19,1\% volt, és a szavatoló tőke 90\%-át az alapvető elsődleges tőke (CET1) adja. A jobb minőségű tőkének köszönhetően a bankok stressztűrő képessége növekszik, és nőhet a hitelkihelyezés. ${ }^{10}$ Ezenkívül a szabályozásban megfogalmazott egyedi szintű kockázatkezelés ellenállóvá teszi a bankokat a likviditási hiánnyal szemben, és garantálja a jövedelmezőséget. ${ }^{11} \mathrm{~A}$ folyamatosan ellenőrzött, transzparens bankpiac kiszámíthatóbb környezetet is teremt, és hozzájárul a bizalom újraépítéséhez a pénzügyi szektor irányába. ${ }^{12} \mathrm{~A}$ stabil bankrendszer javítja a gazdaság teljesítményét és stabilitását. A tőkeszabály tartalékképzést szorgalmaz, amely megakadályozza a túlzott banki kockázatvállalást és növeli az ellenálló képességet a gazdasági válságokkal szemben. ${ }^{13}$ Ugyanakkor számolni kell gazdasági és banki költségekkel is, amely megjelenhet a hitelkamatok emelkedésében. ${ }^{14}$ Hiszen, a növekvő tőkeelvárás miatt növekszik a tőkeköltség, amely egy bizonyos szint felett csökkentheti a banki jövedelmezőséget adott hitelezési politika mellett. Ebben a helyzetben a hozamcsökkenés a kamatbevételek növelésével

Joshua D. Coval - Anjan Thakor: Financial Intermediation as a Beliefs-Bridge between Optimists and Pessimists. Journal of Financial Economics, 75. (2005), 3. 535-569.

11 Szombati Anikó: Bázel III. rendszerszintű hatásai itthon és Európában. MNB Szemle, 5. (2010), 4. 33-42.

12 Katharina Pistor: A Legal Theory of Finance. Columbia Law School. Public Law \& Legal Theory Working Paper Group, (2013). 13-348. 1-54.

13 Holmsen (2014) i. m. 2.

14 Bank for International Settlements (BCBS): An assessment of the long-term economic impact of stronger capital and liquidity requirements. Basel, 2010. 
kompenzálható, amely egyenlő a hitelkamat emelésével a banki jövedelmezőség fenntartására érdekében. ${ }^{15}$

A nemzetközi kutatások ebben a témában egyértelmű eredményeket mutatnak. Elsőként King ${ }^{16}$ kutatási eredménye alapján a tőkekövetelmény 1 százaléknyi szigorításának költségét a kamatmarzs 15 bázispontnyi emelése kompenzálja, amely végső soron a kamatszint emelkedését jelenti. A témában más szerző is folytatott kutatásokat, és megerősítették a kamatemelkedésre vonatkozó eredményt. Más szerzők globális mintán vizsgálódtak és 0,1-29,7 bázispontos emelkedést azonosítottak, ${ }^{17}$ amíg az USA esetében 9,5 bázispontos hitelkamat-emelkedést mutattak ki. ${ }^{18}$ Barbora Šútorová és Petr Teplý az Európai Unióban vizsgálta a tőkeemelés hatását a kamatszintekre, és szintén kimutatható, de mérsékelt 18,8 bázispontos kamatemelést határoztak meg 1 százaléknyi tőkekövetelmény-emelkedés mellett. ${ }^{19} \mathrm{Az}$ Európai Központi Bank tanulmánya is vizsgálta a bankok múködését kereslet okozta gazdasági és banki tőkére ható stressz esetén. Megállapításaik szerint a tőkét ért stresszhelyzetre a bankok a portfóliókockázat csökkentésével és a hitelezés visszafogásával válaszolnak. Ennek eredményeként csökken a kockázattal súlyozott eszközérték, és ennek megfelelően az elvárt minimumtőkeszint is. Végső soron a tőkeminimum szintjének emelése a hitelezési tevékenység mérséklődésével és a kamatszint emelésével járhat, amely a GDP csökkenéséhez is vezet. ${ }^{20}$

A kutatás célja a tőkeszint emelésének hatására bekövetkező hitelkamat-növekedés felmérése a magyar bankpiacon. A téma aktualitását adja, hogy a Bázel III. szabályozás bevezetésére és az alkalmazkodási periódusra szánt hétéves ciklus véget ért, és az elvárt tőkeszint a csúcsára emelkedett.

\section{Kutatásmódszertan}

A kutatás célja a magyar bankszektor esetében feltérképezni a tőkemegfelelési mutató 1 százalékos emelésének hatását a hitelkamatokra. A kutatáshoz alkalmazott úgynevezett „mapping” módszert King ${ }^{21}$ alkalmazta először a tőkeszintemelés kamatmarzsra gyakorolt hatásának felmérésére. Matejašák a tőkemegfelelési mutató emelése, a hitelek kamatszintje és ROE-mutatója közötti összefüggés meghatározására használta a cseh

$15 \quad$ Nguyet Thi Minh Phi - Hanh Thi Hong Hoang - Farhad Taghizadeh-Hesary - Naoyuki Yoshino: The Basel Capital Requirement, Lending Interest Rate, and Aggregate Economic Growth: An Empirical Study of Viet Nam. ADBI Working Paper Series, (2019), 916. 1-24.

16 Michael R. King: Mapping capital and liquidity requirements to bank lending spreads. BIS Working Papers, (2010), 324. 1-35.

17 Sun Eae Chun - Hoon Kim - Wonhong Ko: The Impact of Strengthened Basel III Banking Regulation on Lending Spreads: Comparisons across Countries and Business Models. BOK Working paper, (2012), 2012-15. 1-44.

18 David Glancy - Robert Kurtzman: How do Capital Requirements Affect Loan Rates? Evidence from High Volatility Commercial Real Estate. Finance and Economics Discussion Series, (2018), 079. 1-43.

19 Barbora Šútorová - Petr Teplý: The Impact of Basel III on Lending Rates of EU Banks. Journal of Economics and Finance (Finance a úvěr), 63. (2013), 3. 226-243.

20 Derrick Kanngiesser et alii: Estimating the impact of shocks to bank capital in the euro area. ECB Working Paper, (2017), 2077. 1-36.

$21 \quad$ King (2010) i. m. 5. 
bankszektor esetében. ${ }^{22}$ A kutatásban használt modell a Matejašák által bemutatott „mapping” módszert követi a kezdeti feltételezések elfogadásában, és az alapvető egyenletek és azok közötti összefüggések felírásában. Azonban a jelen kutatásban használt módszertan különbözik a vizsgálati csoport és a kutatási cél meghatározásában. Matejašák a tőkemegfelelési mutató emelésére kötelezett hitelintézetek adatait vizsgálta, illetve kiegészítette elemzését a ROE változtatásának lehetőségével is. ${ }^{23}$ Ebben az esetben a tőkemegfelelési mutatóhoz történő alkalmazkodás a ROE csökkenésével történik, és nem eredményez kamatemelkedést. Ezzel szemben ennek a kutatásnak a célcsoportja a részvénytársasági formában működő hitelintézetek csoportja, és a célja korlátozódik a lehetséges kamatemelés szintjének meghatározására. A modell nem vizsgálja a bankok üzleti stratégiáját és a tulajdonosok által kijelölt tőkemenedzsmentcélokat, ezért nem számol a ROE-szint változásának kérdésével. Az üzemméret sajátosságaiból adódó különbségek meghatározása érdekében a hitelintézeti adatokat a bankok mérete szerint nagy, közepes és kis méretű csoportban elemezi. Ezenkívül a kamatbevétel pontosabb meghatározásához elkülöníti a lakossági és vállalati hitelállományok kamatszintjét. Így a hitelállományra számolt kamat egyenlő a hitelszegmensek szerinti állománnyal súlyozott kamatszinttel. A forrásoldali kamatszintek meghatározásánál szintén módosítás történt, mivel a hitelintézeti szektor rövid és hosszú lejáratú hiteleinek kamatszintjére vonatkozó információ nem áll rendelkezésre publikus formában. Ezért ennek helyettesítésére a bankközi kamatok átlagát használja a modell, vagyis a napi BUBOR átlagát. A BUBOR használata szakértői becslés alapján történt, mint a kamatköltségek meghatározásához felszámolható kamatszint. A vizsgálat eredményéből következtetés vonható le a bankméret szerinti kamatemelés mértékére is, amely így pontosabb, mint az eredeti modell, és jobban kifejezi a valóságban bekövetkező emelkedést. A módszer nem mutatja a tőkeemelés folyamatát, csak a statikus állapotot értékeli. Az adatok forrása a pénzintézetek mérlegei, eredménykimutatásai, amelyet az MNB Aranykönyv nevü publikációjában évente közzétesz.

\section{Modell}

A modell építése egy bank egyszerúsített mérlegének meghatározásával kezdődik. A banki eszközök (E) összességét a készpénz (K), bankközi követelések (BK), kereskedésre szánt eszközök (KE), hitelek (H), értékpapírok (ÉP) és egyéb eszközök (EE) adják. Amíg a forrásokat (F) a betétek (B), bankközi források (BF), hitelezői jogot megtestesítő értékpapírok (HÉ), felvett hitelek (FH) és egyéb források (EF) képezik. A modell nem különbözteti meg a különböző hiteltípusokat, így a vállalati és lakossági ügyletek is a hitelek csoportban találhatók.

(1) $\mathrm{E}=\mathrm{K}+\mathrm{BK}+\mathrm{KE}+\mathrm{H}+\mathrm{E} P+\mathrm{EE}$

(2) $\mathrm{F}=\mathrm{B}+\mathrm{BF}+\mathrm{HE}+\mathrm{FH}+\mathrm{EF}$

22 Matejašák (2014) i. m. 4.

23 Matejašák (2014) i. m. 4. 
Az egyszerűsített bankmérleghez tartozó eredménykimutatás fő mutatója a nettó bevétel (NB), amely a kamatjellegű (KB) és nem kamatjellegű (NKB) bevételekből származó eredmény összessége, a múködési költség (MK) és az adó $(A)$ levonása után.

(3) $\mathrm{NB}=(\mathrm{KB}+\mathrm{NKB})-\mathrm{MK} \times(1-\mathrm{A})$

A kamatjellegű bevételek (KB) fő forrása az ügyfelekkel szembeni követelésekbőláll, azaz hitelek, befektetések és bankközi követelésekre kapott kamat. A kamatköltségek (KK) alapját a betétekre, bankközi forrásokra és felvett hitelekre fizetett kamat adja. A nem kamatjellegú bevételeket elsősorban a díjak és jutalékok képezik, valamint a kereskedési célú eszközök és kamatozó források után realizált jövedelem. Múködési költség (MK) alatt bankok esetében leginkább a személyi, adminisztratív költség értendő, illetve a napi múködéshez szükséges egyéb költségek.

A kamatbevételt (KB) elsősorban a hitelek után beszedett kamat adja, amelyen belül szükségesnek tartjuk az eredeti modell kiegészítését és a lakossági és vállalati hitelek megkülönböztetését, a futamidő figyelembevételével. Ez alapján a kamatbevételek a lakossági és vállalati hitelekre számolt, futamidővel súlyozott átlagaként áll elő, a következő egyenlettel:

(4) $\mathrm{KB}=\mathrm{Lak} \times \mathrm{r}_{\mathrm{lak}}+$ Váll $\times \mathrm{r}_{\text {váll }}$

A kamatköltség (KK) felírható a betéti kamatok (bk), a rövid (rr) és hosszú távú (rh) kamatok és a hozzájuk tartozó állományok szorzatának összegeként, amelyet a következő egyenlet mutat.

(5) $\mathrm{KK}=\mathrm{bk} \times \mathrm{B}+\mathrm{rr} \times(\mathrm{BF}+\mathrm{HÉ}+\mathrm{EF})+\mathrm{rh} \times \mathrm{FH}$

A tanulmányban szereplő kalkuláció pontosságát a kamatszintek és a hozzájuk tartozó állományok meghatározása adja. A fizetett kamatok jelentős részét a betétekre adott kamat jelenti, amíg a kapott kamat a hitelekre számolt kamatszint. A modell a fizetett kamat esetében az átlagos, éven belüli lekötésekre adott átlagos piaci kamatszintet használja. A fizetett kamatok esetében pedig a lakossági és vállalati hitelekre számolt állománnyal súlyozott átlagos kamatszintet.

Ezenkívül a modellben kulcsszerepe van a ROE-mutatónak, amely a sajáttőke-arányos megtérülést mutatja, illetve a saját tőke költségét, azaz elvárt hozamát ( $\left.r_{\text {saját tỏke }}\right)$. A mutató a nettó bevétel és a saját tőke arányában határozható meg.

(6) $r_{\text {saját tôke }}=\mathrm{ROE}=\mathrm{NB} /$ saját tőke

A banki múködés finanszírozásának szempontjából a betéti forrás a legolcsóbb, amelyet a rövid távú és hosszú távú hitelek követnek. A saját tőke költsége a legnagyobb, amely egyben mutatja a tulajdonosok által hosszú távon elvárt megtérülést is. ${ }^{24}$

A modell végső egyenlete a tőkemegfelelési mutató (TMM) számítására vonatkozó összefüggést mutatja, amely a szabályozói tőke (T) és a kockázattal súlyozott eszközérték (RWA) hányadosa.

(7) $\mathrm{TMM}=\mathrm{T} / \mathrm{RWA}$

$24 \quad$ Franco Modigliani - Merton H. Miller: The Cost of Capital, Corporation Finance and the Theory of Investment. The American Economic Review, 48. (1958), 3. 261-297. 
A felírt egyenletek (1-7.) mutatják az 1 százaléknyi tókeemelés hatását a kamatszintre, figyelembe véve azt, hogy a kockázattal súlyozott eszközértékre számolt tőke menynyisége a szabályozói elvárás szerinti célértékre növekszik. Feltételezzük továbbá, hogy az eszközök összetétele és kockázati szintje változatlan marad, így addicionális kockázati költség nem lép fel. Ebben az esetben azonban a növekedő tőkeszinttel párhuzamosan romlik a sajáttőke-arányos megtérülés, vagyis a ROE. A bank tulajdonosi köre számos intézkedést hozhat ebben az esetben: dönthet az alacsonyabb ROE-szint elfogadása mellett, vagy változtathat üzleti stratégiáján, és jövedelmezőbb ügyfélszegmensek vagy termékek irányába mozdul el a múködés, esetleg csökkentheti az adminisztratív költségeket és növelheti a díjak és jutalékok emeléséből származó nem kamatjellegű bevételeket. A modell feltételezése alapján a bank tulajdonosi köre az eredeti ROE-szintet és -megtérülést kívánja fenntartani. Ennek elsődleges forrása a kamatbevétel, ezért a bank növeli a hitelállományra szedett kamatot. A hitelek kamatszintje (a) tehát olyan mértékben növekszik, amely elégséges a korábbi ROE-szint fenntartásához, vagyis a kamatváltozás mértéke egyenlő az új kamatbevétel (KB1) és a régi kamatbevétel (KB) különbségének és a hitelállománynak a hányadosával.

(8) $a=\left(\mathrm{KB}_{1}-\mathrm{KB}\right) / \mathrm{H}$

A korábbi egyenletek felhasználásával a kamatbevételt felírhatjuk a ROE és a saját tőke szorzataként számított nettó bevétel és az egyéb bevételek és költségek különbségeként, amely fixálja a ROE-szintet.

(9) $a=\left\{\left(\mathrm{ROE}_{\mathrm{t}+1} \times\right.\right.$ saját tôke $\left.\left.\mathrm{t}_{\mathrm{t}+1} / 1-\mathrm{A}\right)-\left(\mathrm{KK}_{\mathrm{t}+1}+\mathrm{NKB}_{\mathrm{t}+1}\right)\right\}-\mathrm{KB}_{\mathrm{t}} / \mathrm{H}_{\mathrm{t}+1}$

Matejašák (2015) kiemeli, hogy a kamatemelkedés mértéke függ a bank finanszírozási stratégiájától és a tulajdonosok döntésétől is. Egészen addig, amíg a hosszú távú hiteleket tőkével helyettesítik, és a tőke és hitel költsége stagnál, a hitelek kamatszintje lineárisan nő a tőkeemeléssel párhuzamosan. Abban az esetben, ha a bank az olcsóbb tőkeköltségú rövid lejáratú hiteleket drágább finanszírozású tőkére cseréli, akkor a hitelekre számított kamatemelkedés nagyobb lehet, mivel mérsékeltebb a kamatköltségben bekövetkezett csökkenés. A drágább banki finanszírozás mellett a tőkemegfelelési mutató fenntartása költségesebb, amelynek eredményeképpen szúkülhet a hitelkínálat, és hosszú távon negatívan hathat a pénzügyi stabilitásra is.

\section{A magyar hitelintézetek helyzete}

Az elemzés elkészítését a Magyar Nemzeti Bank által készített publikus felügyeleti statisztika és kamatstatisztika segítette. A mérlegre és eredménykimutatásra vonatkozó adat 2018. év végi állapotot mutat, amelyet a 2018-ra vonatkozó súlyozott számtani átlaggal elóállított kamatszintek egészítenek ki.

$\mathrm{Az}$ elemzés 27 darab részvénytársasági formában múködő hitelintézet adatait használja fel. A mintában nem szerepelnek a lakástakarék-pénztárak, a jelzálogbankok és a szakosított pénzügyi intézmények, mint a Keler Zrt., a Magyar Fejlesztési Bank és az EXIM Bank. Az intézmények üzemméret szerint három csoportra oszthatók. A nagy méretű bankok csoportját az 1000 milliárd feletti mérlegfőösszegú intézetek 
alkotják, 1000 milliárd Ft alatti mérlegfőösszeggel szerepelnek a közepes méretủ bankok és 100 millió Ft mérlegfőösszeg alatt a kis méretű hitelintézetek. A táblázat a mérlegfőösszeg-arányos eszköz- és forrásértékeket mutatja a bankok mérete szerinti csoportosításban.

1. táblázat

A magyar bankok egyszerüsített mérlegszerkezete, 2018. december

\begin{tabular}{|l|r|r|r|}
\hline \multicolumn{1}{|c|}{ Egyszerúsített banki mérleg, 2018 } & $\begin{array}{c}\text { Nagy méretü } \\
\text { bankok }\end{array}$ & $\begin{array}{c}\text { Közepes } \\
\text { méretü bankok }\end{array}$ & $\begin{array}{c}\text { Kis méretü } \\
\text { bankok }\end{array}$ \\
\hline Pénztár és elszámolási számlák & $7 \%$ & $8 \%$ & $14 \%$ \\
\hline Értékpapírok összesen & $31 \%$ & $20 \%$ & $19 \%$ \\
\hline Jegybanki és bankközi betétek & $7 \%$ & $9 \%$ & $9 \%$ \\
\hline Hitelek & $46 \%$ & $60 \%$ & $52 \%$ \\
\hline $\begin{array}{l}\text { Leányvállalatokba, közös vállalkozásokba, } \\
\text { valamint társult vállalkozásokba történt } \\
\text { befektetések }\end{array}$ & $5 \%$ & $0 \%$ & $1 \%$ \\
\hline Aktív elszámolások és egyéb eszközök & $3 \%$ & $1 \%$ & $5 \%$ \\
\hline Saját eszközök & $1 \%$ & $1 \%$ & $0 \%$ \\
\hline Eszközök összesen & $100 \%$ & $100 \%$ & $100 \%$ \\
\hline Összes betét & $73 \%$ & $67 \%$ & $70 \%$ \\
\hline Felvett hitelek & $9 \%$ & $22 \%$ & $21 \%$ \\
\hline Hitelezői jogot megtestesítő értékpapírok & $1 \%$ & $0 \%$ & $0 \%$ \\
\hline Passzív elszámolások & $4 \%$ & $1 \%$ & $1 \%$ \\
\hline Céltartalék & $0 \%$ & $0 \%$ & $0 \%$ \\
\hline Saját tőke & $13 \%$ & $9 \%$ & $8 \%$ \\
\hline Források összesen & $100 \%$ & $100 \%$ & $100 \%$ \\
\hline
\end{tabular}

Forrás: a szerző szerkesztése

A magyar piac koncentrált, a legnagyobb kilenc bank a piacon található összes eszközérték több, mint 87,5\%-át teszi ki. Ezek az intézmények jellemzően külföldi tulajdonossal rendelkeznek, és a lakossági jelzálog és fedezetlen hiteltermékek mellett a kockázatosabb vállalati és projekthitelezéssel is foglalkoznak. A koncentrációt növelte, hogy 2018-ban a takarékszövetkezeti rendszer konszolidációja folyamán megjelent a Magyar Takarékszövetkezeti Bank a nagybankok csoportjában. A közepes és kis méretű bankok inkább a lakossági hitelezésben aktívak és magyar tulajdonban állnak, rendre az összes eszközérték 10,9\% és 1,7\%-ával rendelkeznek. A mérlegen belüli tételek aránya megfelel a szokásos banki működésnek, eszközoldalon a hitelek, míg forrásoldalon a betétek vannak túlsúlyban. A mérleg- és eredmény-összetétel azonban eltéréseket mutat a bankok üzemmérete szerint. A nagybankok esetében eszközoldalon a hitelállomány mérlegfőösszeghez viszonyított aránya 46\%, amelyet 31\%-kal követ az értékpapírok csoportja. A közepes méretű bankok hitelállománya a mérlegfőösszeg 60\%-át teszik ki, amíg az értékpapír részaránya 20\% körül alakul. A kisebb bankok hasonló eszközöszszetétel mellett nagyobb részarányú (14\%) pénztár- és elszámolásiszámla-állománnyal és jellemzően háztartási hitelállománnyal rendelkeznek. A forrásoldal ugyanakkor 
tükrözi a nagybankok tőkeerős helyzetét. A felvett hitelek aránya csupán 9\%, amíg a saját tőke eléri a 13\%-ot. A közepes és kisebb bankok esetében nagyobb mértékű (21\%) felvetthitel-állomány látható, és alacsonyabb a saját tőke részaránya. A felvett hitelek nagyobb súlya a külföldi tőkeerős anyavállalat hiányát mutatja, és nagyobb kitettséget jelent a jegybanki alapkamat-változások hatásának.

A banki üzleti eredmény alapvetően a kamateredményből, a nem kamatjellegű eredményből, illetve az üzleti tevékenységhez kapcsolódó költségből, azaz a működési költségből tevődik össze. A közepes méretű bankok esetében a kamateredmény adja az összes eredmény túlnyomó többségét (70\%), azonban a nagy és kisebb bankok esetében jelentős a jutalék és osztalékeredmény is. A nagybankok esetében az értékpapír (állampapír) portfólión elért árfolyamnyereség is ellensúlyozza a kockázatosabb hitelportfólióból eredő kockázati többletköltséget és veszteséget. A működési költség szintje a nagybankok esetében a legmagasabb, azonban a bevételhez viszonyított aránya alacsonyabb (61\%), mint a közepes (77\%) és kisebb (73\%) bankok csoportjában. Az eltérés oka az üzemméretből eredő méretgazdaságosság, amely csak akkor tud érvényesülni, ha megfelelő eredménnyel társul. A múködési költségeken belül általánosságban $75 \%$ körüli részarányt mutat a személyi és IT-kiadások összege. A hosszú távú stratégia része számos nagybanknál a digitális csatorna fejlesztése, amely jelentős befektetéseket igényel, de később hozzájárulhat a hatékonyságnöveléshez. A közepes és kisebb bankok méretükből adódóan szerényebb összegeket tudnak elkülöníteni erre a célra. Ugyanakkor a fejlesztés elengedhetetlen a működési hatékonyság javításához, és elmaradása esetén csökkenhet a ROE-szint, és növekedhet a kamatszint, aminek következtében lemaradnak a piaci versenyben.

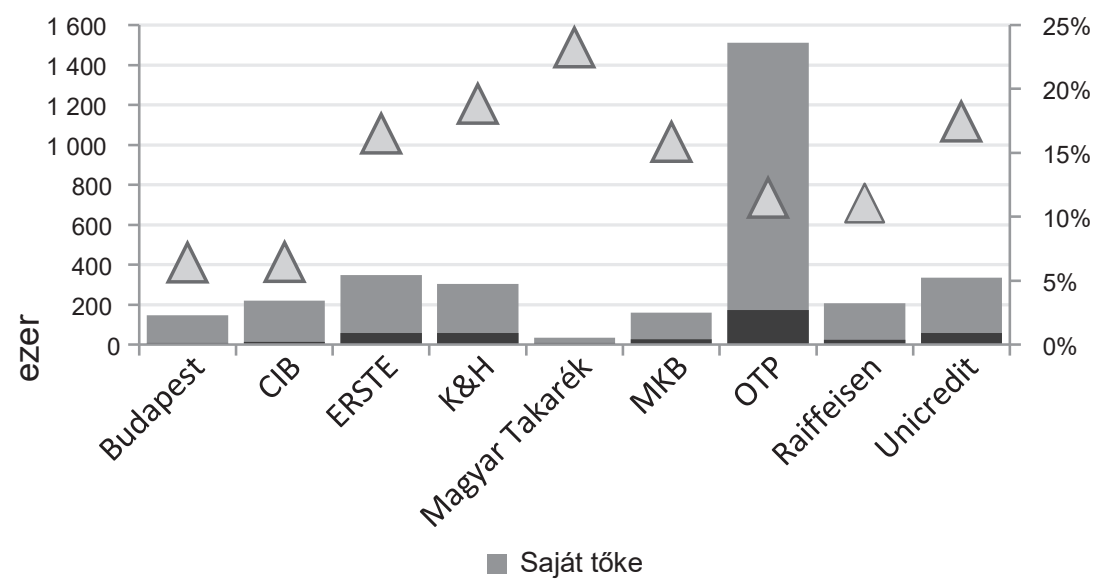

2. ábra

Nagy méretü bankok saját tőke és adózott eredmény állománya a ROE-mutató százalékos értékével

Forrás: a szerző szerkesztése

A vizsgált bankok jövedelmezősége - mint a saját tőke és az adózott eredmény hányadosa - jelentős eltéréseket mutat a bankméret és üzletpolitika függvényében. 
A nagybankok ROE-mutatója átlagosan $14 \%$ körül alakult 2018. december végén. A csoport 362 milliárd Ft átlagos saját tőkével és 47 millió Ft-os adózás utáni eredménnyel rendelkezik. A 2. ábrán jól látszik a magyar bankpiac kiemelkedő szereplője, az OTP Bank, amely 1500 milliárd Ft-os sajáttőke-értékkel és 173 milliárd Ft-os adózott eredménnyel 11\%-os tőkearányos megtérülési mutatót ért el 2018-ban. Kiemelkedő sajáttőke-arányos megtérülést mutat a K\&H, az ERSTE Bank és az Unicredit Bank, amely részben olyan egyedi hatásoknak köszönhető, mint a céltartalék-visszaírás. Illetve az Unicredit esetében a költségszint alacsony szinten tartásához hozzájárul az IT-szolgáltatás kiszervezése az anyabanki szervezethez.

A 3. ábra mutatja a közepes üzemméretű bankok adatait. Ezek a hitelintézetek általánosságban alacsonyabb sajáttőke-arányos megtérüléssel rendelkeznek, mint a nagyobb üzemmérettel rendelkező intézmények. Az intézmények 2018-ban átlagosan 28,9 milliárd forintos sajáttőke-érték mellett 3,2 milliárd forintos adózott eredményt tudtak elérni. ROE-mutatójuk átlagosan 10\%, amely azonban nagyobb szórást mutat, mint a nagybankok csoportja. A Cetelem és a Merkantil bank 30\%-os és 21\%-os ROE-mutatóval a nagybankok legmagasabb tőkemegtérülését is meghaladja, amíg a Magnet Bank 14\%-os ROE-mutatóval a nagybankok átlagértékének felel meg. A példájuk mutatja, hogy specifikus termékek és az ahhoz tartozó üzletpolitika kialakításával magasabb jövedelmezőség érhető el, amely azonban magasabb tőkekövetelménnyel párosul. A Magnet Bank esetében az online tér által nyújtott megoldások pozitív hatásai láthatók, amelyek segítik a múködési költségek alacsony szinten tartását és a magasabb szintű jövedelmezőséget.

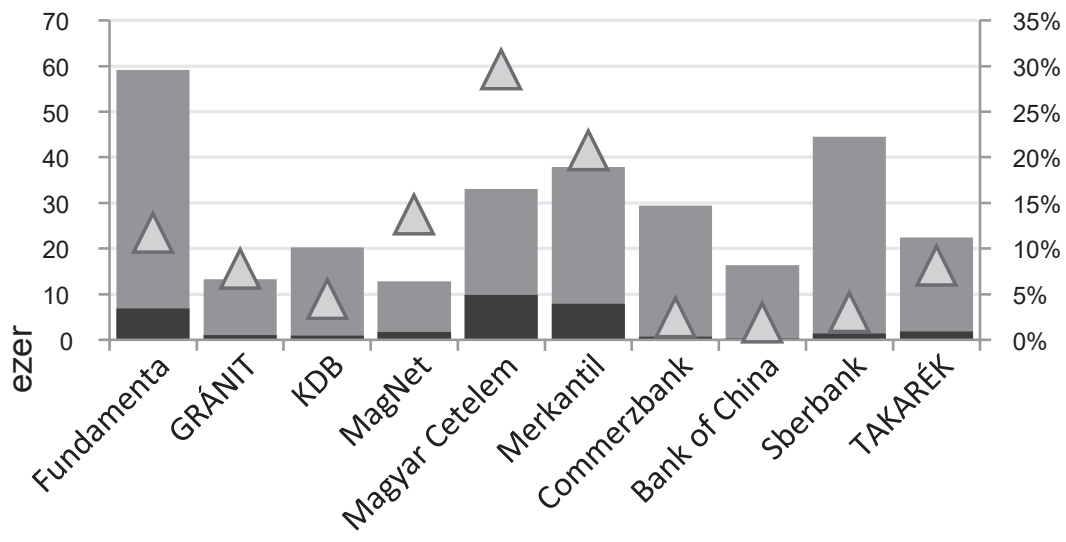

Saját tőke

3. ábra

Közepes méretü bankok saját tôke és adózott eredmény állománya a ROE-mutató százalékos értékével

Forrás: a szerző szerkesztése

Az utolsó (4.) ábra a kis méretű, átlagosan 4,7 milliárd forint saját tőkével rendelkező bankok jövedelmezőségét mutatja. Az átlagos ROE-mutató értéke ebben a csoportban 3\%, 133 millió forintos adózott eredmény mellett. Kiemelkedő ROE-értéket mutat 
a Kinizsi Bank és a Sopron Bank, amely alátámasztja a múködési költségek alacsony szinten tartásának előnyeit. Az ábra jól szemlélteti, hogy egy bizonyos üzemméret alatt már sokkal szerényebb sajáttőke-arányos jövedelmezőségi mutatókat tudnak elérni az intézmények. Ennek oka lehet a méretgazdaságosság hiánya vagy a korlátozott területi lefedettség is.

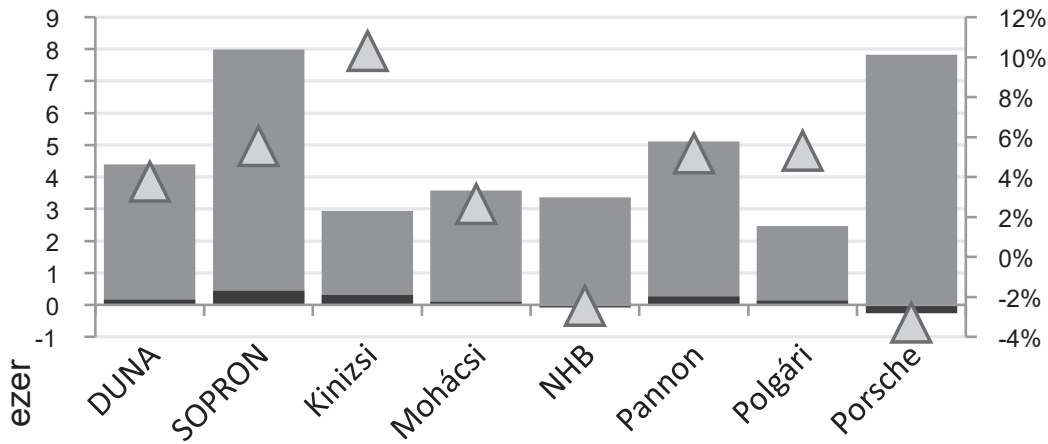

Saját tőke

4. ábra

Kis méretü bankok saját tôke és adózott eredmény állománya a ROE-mutató százalékos értékével

Forrás: a szerző szerkesztése

\section{Eredmények}

A fent ismertetett magyar hitelintézetekre vonatkozó banki mérleg és eredménykimutatás alapján felállított modell megmutatja, hogy a szabályozói elvárás alapján számolt tőkemegfelelési mutató (TMM) 1\%-os növelése mellett hogyan változik a hitelek kamatszintje a ROE szinten tartása és az üzletpolitika változatlansága mellett. Fontos feltétel, hogy a tulajdonosok nem kívánják a tőkemegfelelési mutató emeléséből adódó jövedelemkiesést jóváhagyni, és céljuk a banki múködés fő bevételének, a kamatjövedelemnek a növelése. Ennek megfelelően a ROE fenntartásához szükséges jövedelem a hitelekre számolt kamatbevételből ered.

A modell segítségével végrehajtott számítás eredményét a lenti táblázat mutatja, a bankok üzemmérete szerinti csoportosításban. Az első oszlopban a tőkemutató 1\%-os emelése található százalékonként jelölve, amíg a többi oszlop a kamatnövekedés mértékét mutatja az emelkedés függvényében. Az eredmények alapján a tőkemegfelelési mutató 1\%-os emelésének hatása az üzemméret csökkenésével párhuzamosan csökken. Vagyis a kisebb méretű bankokra kevésbé van hatással a tőkeemelés, a nagy méretű bankok esetében az 1\%-os tőkemegfelelésimutató-emelkedés 18 bázispontos kamatszintemelést mutat, amely $2 \%$-os emelés mellett 36 , majd $3 \%$ mellett 54 bázispontra nő. A közepes méretű bankok csoportja ennél alacsonyabb, 14 bázispontnyi kamatemelést mutat, amely 3\%-os tőkemegfelelésimutató-emelés esetén 41 bázispontra nőhet. A kisebb méretű bankok esetében a legkisebb a tőkemegfelelési mutató emelésének 
hatása a kamatszintre. Az 1\%-os emelkedés 15 bázispontnyi kamatszintemelést eredményezhet, a 3\%-os emelés pedig 44 bázispontos kamatszint-emelkedést.

2. táblázat

A kamatnövekedés bankméret szerinti aránya a tökemegfelelési mutató emelésének függvényében

\begin{tabular}{|c|c|c|c|c|c|}
\hline \multicolumn{7}{|c|}{ Bankméret/Kamatnövekedés } \\
\hline \multicolumn{2}{|c|}{ TMM növekedés } & Összesen & Nagy & Közepes & Kicsi \\
\hline & $1 \%$ & $0,17 \%$ & $0,18 \%$ & $0,14 \%$ & $0,15 \%$ \\
\hline & $2 \%$ & $0,34 \%$ & $0,36 \%$ & $0,27 \%$ & $0,29 \%$ \\
\hline & $3 \%$ & $0,51 \%$ & $0,54 \%$ & $0,41 \%$ & $0,44 \%$ \\
\hline
\end{tabular}

Forrás: a szerző szerkesztése

\section{Következtetés}

A Bázel III. pénzügyi szabályozás szigorúbb likviditási és tőkekövetelményeket ír elő a bankok számára, amelyeknek hatása a nemzetgazdasági adottságoktól függően érvényesül. A kutatás a szabályozás egyik kulcstényezőjét, a tőkemegfelelésre vonatkozó szigorítást emeli ki és vizsgálja a hitelkamat viszonyában a magyar bankpiacon. A vizsgálatot az úgyevezett „mapping” módszer segítette, amely szerint a magyar bankrendszerben a tőkemegfelelési mutató 1\%-os emelése jövedelemoldalon 17 bázispontos kamatemeléssel ellensúlyozható. A modell eredménye a kiinduló feltételek mellett irányadó, vagyis feltételezi a banki stratégia, üzletpolitika és ROE állandóságát, valamint a hitelportfolió kockázatának változatlanságát. Az eredmény alapvetően összhangban van a korábbi empirikus kutatások eredményével. Šútorová és Teplý átlagosan 18,8 bázispontos kamatemelkedést határozott meg az Európai Unióban, ${ }^{25}$ amellyel a magyar nagybankokra számolt 18 bázispontos emelkedés csaknem megegyezik. Matejašák ugyanakkor a cseh bankszektorra 6,3 bázispontos emelkedést azonosított, amely az európai uniós és a magyarországi piacra számolt kamatemelési szinthez képest is jelentősen alacsonyabb. ${ }^{26}$

A jövőre nézve a kamatemelési hatás figyelembevétele a tőkemegfelelési politika megfogalmazásánál segítheti a szabályozói arbitrázs csökkenését. Továbbá a vizsgálat igazolja a kamatemelés gazdasági és társadalmi hatását, mivel a nagybankok jelentősen befolyásolják az egész gazdasági rendszert. ${ }^{27}$ Összességében a legmagasabb, nagybankok esetében számolt 18 bázispontos kamatemelés a magyar bankszektorban nem jelentős mértékű, és az idő során graduálisan jelentkezhet a szabályozásban előírt tőkemegfelelési mutató emelésével összhangban. A kutatás azt is megmutatja, hogy a kamatemelés nem jelentkezik minden intézménynél egyformán - az üzemmérettől függően -, nagyobb mértékben érinti a nagy méretű bankokat és korlátozottabb mértékben a kisebb mérlegfőösszegú intézményeket. Ennek az eltérésnek az oka a különböző

Šútorová-Teplý (2013) i. m. 5.

Matejašák (2014) i. m. 4.

Kanngiesser et alii (2017) i. m. 6.

Európai Tükör 2020/4. 
méretű bankok mérlegszerkezetének és üzletvitelének a különbsége. A nagyrészt külföldi tulajdonban lévő nagybankok jelentősebb és feltehetően kockázatosabb (például projekthitelek) hitelkitettséggel és nagyobb devizaállománnyal rendelkeznek, amelynek hitel- és árfolyamkockázati felárával számolniuk kell. A kamatemelést ugyanakkor nagymértékben befolyásolja a piaci realitás és a valós tőkefinanszírozás. A bankpiaci koncentráció és az új ügyfelek megszerzését célzó üzleti stratégia jelentős versenyt generálhat a magyar piacon, amely miatt esetleg elmaradhat vagy csökkenhet a kamatemelés. Ezenkívül a kamatemelés hatását gyengíthetik még egyéb tőkepiaci finanszírozási csatornák is, amelyek alternatív forrást biztosítanak. Például az MNB vállalati kötvény vásárlási programja, vagy a közösségi finanszírozást támogató fintech cégek. Lakossági hitelezésben enyhítő tényezők az MNB által támogatott hitelezési programok, amelyek valamiképpen korlátozzák a felszámolható hitelkamat maximumértékét (például minősített fogyasztóbarát hitel vagy babaváró hitel program). A kamatnövekedés elmaradása esetén az intézmények ROE-szintje csökkenhet, amelyet költségcsökkentéssel, hatékonyságnöveléssel igyekeznek kompenzálni, vagy egyéb bevételi forrással. A tőkekövetelmény változásához való alkalmazkodást a külföldi anyabankok kedvező árszintű forrása is támogatja a nagybankok esetében, amelyek ezzel profitnövekedést is elérhetnek. A kisebb, hazai bankoknak nem áll rendelkezésre hasonló forrás, így múködési hatékonyságuk növelése és az IT-fejlesztés esetükben még fontosabb.

$\mathrm{Az}$ eredmények gyakorlati felhasználásának területe lehet a lakosságihitel-terhek újraszámolása az alapkamat emelése esetén, hiszen a 17 bázispontos kamatemelés önmagában nem okoz problémát, de egy kamatemelési ciklussal párhuzamosan már emelheti az adósságterhet. A kamatemelkedés tényének figyelembevétele fontos lehet még a hosszabb kamatperiódusú hitelek átszámolása során is. A korábban felvett hoszszabb (5 és 10 éves) kamatperiódussal rendelkező ügyfelek a kamatperiódus lejáratakor jelentősebb kamatemeléssel nézhetnek szembe, amennyiben a tőkemegfelelési mutató és az alapkamat emelése párhuzamosan történik. Az 5 és 10 éves kamatperiódussal rendelkező hiteltermékek alapvetően biztonságosabb alternatívát nyújtanak az ügyfeleknek, azonban a lakáscélú hitelek átlagos futamideje növekszik, így egy hiteltermék akár háromszor is újraárazódik a teljes futamidő alatt. További elemzési irányt ad a kamatemelés lehetőségének mérlegelése az üzleti stratégia viszonyában, amely meghatározza a bank finanszírozási stratégiáját és üzletpolitikáját, illetve a kamatemelés hatásának számszerú értékelése az aktuális jegybanki alapkamat és a BUBOR viszonylatában, amelyek befolyásolhatják a kamatszint emelkedés mértékét.

\section{Felhasznált irodalom}

Bank for International Settlements (BCBS): An assessment of the long-term economic impact of stronger capital and liquidity requirements. Basel, Switzerland, 2010.

Coval, Joshua D. - Anjan Thakor: Financial Intermediations as Beliefs-Bridge between Optimists and Pessimists. Journal of Financial Economics, 75. (2005), 3. 535569. Online: https://doi.org/10.1016/j.jfineco.2004.02.005 
Fábián Gergely - Vonnák Balázs (szerk.): Átalakulóban a magyar bankrendszer. Vitaindító a magyar bankrendszerre vonatkozó konszenzusos jövőkép kialakításához. MNB-tanulmányok, (2014), különszám. 1-62.

Glancy, David - Robert Kurtzman: How do Capital Requirements Affect Loan Rates? Evidence from High Volatility Commercial Real Estate. Finance and Economics Discussion Series, (2018), 079. 1-43. Online: https://doi.org/10.17016/feds.2018.079

Holmsen, Amund: The theoretical background for macroprudential policy. Norges Bank's Finance Workshop, Oslo, 9 October 2014.

Kanngiesser, Derrick - Reiner Martin - Laurent Maurin - Diego Moccero: Estimating the impact of shocks to bank capital in the euro area. ECB Working Paper, (2017), 2077. 1-36. Online: www.ecb.europa.eu/pub/pdf/scpwps/ecb.wp2077.en.pdf

King, Michael R.: Mapping capital and liquidity requirements to bank lending spreads. BIS Working Papers, (2010), 324. 1-35. Online: www.bis.org/publ/work324.pdf

Kutasi, Gábor: Multinational Banks: Protective Factors of Financial Stability in Central and Eastern Europe? In Szent-Iványi Balázs (szerk.): Foreign Direct Investment in Central and Eastern Europe: Post-crisis Perspectives. New York, Basingstoke, Palgrave, 2017. 171-192. Online: https://doi.org/10.1007/978-3-319-40496-7_8

Magyar Nemzeti Bank (MNB): Aranykönyv. Statisztikai kiadvány, 2019.

Matejašák, Milan: Basel III: Will Borrowing Money from Czech Banks Become More Expensive? European Financial and Accounting Journal, 9. (2014), 2. 4-27. Online: https://doi.org/10.18267/j.efaj.117

Modigliani, Franco - Merton H. Miller: The Cost of Capital, Corporation Finance and the Theory of Investment. The American Economic Review, 48. (1958), 3. 261-297.

Phi, Nguyet Thi Minh - Hanh Thi Hong Hoang - Farhad Taghizadeh-Hesary - Naoyuki Yoshino: The Basel Capital Requirement, Lending Interest Rate, and Aggregate Economic Growth: An Empirical Study of Viet Nam. ADBI Working Paper Series, (2019), 916. 1-24. Online: https://doi.org/10.2139/ssrn.3326960

Pistor, Katharina: A Legal Theory of Finance. Columbia Law School, Public Law \& Legal Theory Working Paper Group, (2013), 13-348. 1-54.

Š́torová, Barbora - Petr Teplý: The Impact of Basel III on Lending Rates of EU Banks. Journal of Economics and Finance, (Finance a úvěr), 63. (2013), 3. 226-243.

Szombati Anikó: Bázel III. rendszerszintű hatásai itthon és Európában. MNB Szemle, 5. (2010), 4. 33-42.

\section{Jogforrások}

Az Európai Parlament és a Tanács hitelintézetek tevékenységéhez való hozzáférésről és a hitelintézetek és befektetési vállalkozások prudenciális felügyeletéről szóló 2013/36/EU irányelve (CRDIV)

Az Európai Parlament és a Tanács hitelintézetekre és befektetési vállalkozásokra vonatkozó prudenciális követelményekről szóló 575/2013/EU rendelete (CRR) 